$10-2017$

\title{
Remembering to Prevent: The Preventive Capacity of Public Memory
}

Kerry E. Whigham

Columbia University

Follow this and additional works at: https://digitalcommons.usf.edu/gsp

\section{Recommended Citation}

Whigham, Kerry E. (2017) "Remembering to Prevent: The Preventive Capacity of Public Memory," Genocide Studies and Prevention: An International Journal: Vol. 11: Iss. 2: 53-71.

DOI:

http://doi.org/10.5038/1911-9933.11.2.1447

Available at: https://digitalcommons.usf.edu/gsp/vol11/iss2/7

This Articles is brought to you for free and open access by the Open Access Journals at Digital Commons @ University of South Florida. It has been accepted for inclusion in Genocide Studies and Prevention: An International Journal by an authorized editor of Digital Commons @ University of South Florida. For more information, please contact digitalcommons@usf.edu. 


\author{
Kerry E. Whigham \\ Columbia University \\ New York City, NY, USA
}

\begin{abstract}
Introduction
In his book In Praise of Forgetting, journalist and social critic David Rieff disputes what he sees as a normative understanding that, in order to prevent future atrocities, we must remember the atrocities of the past. He critiques George Santayana's precept that "he who does not remember the past is condemned to repeat it," arguing that, in some cases, memory of past hatreds does not prevent the recurrence of violence, but encourages it. By highlighting several intractable conflicts that exemplify a contentious relationship with past violence, including Israel-Palestine and the Balkans, Rieff advocates for "forgetting" the past-a strategy that he sees in some cases as the only means of moving forward without the risk of returning to violence. Rieff writes:
\end{abstract}

[F]ar too often collective historical memory as understood and deployed by communities, peoples, and nations...has led to war rather than peace, to rancor and ressentiment $[\mathrm{sic}] \ldots$ rather than reconciliation, and to the determination to exact revenge rather than commit to the hard work of forgiveness. ${ }^{1}$

Rieff's text has garnered significant attention in various news media and among people working in the fields of memory studies and transitional justice. The International Center for Transitional Justice (ICTJ) even hosted an online debate between Rieff and transitional justice advocate Pablo de Greiff on the question "Does collective memory impede reconciliation?" Interestingly, Rieff's theory has received this attention despite the fact that he offers scant evidence for his arguments beyond his own presumptions. He engages with little of the vast literature on memory (the book, in fact, includes no bibliography or citations), especially the plethora of recent work on the subject. ${ }^{2}$ Instead, he opts to quote poetry and literature alongside only a few major theorists of memory, like Pierre Nora. ${ }^{3}$

Rieff claims that the notion that memory of past atrocities like the Holocaust can serve as a deterrent of future violence is "magical thinking, and of a fairly extreme kind." ${ }^{4}$ As proof, he cites the numerous genocides and atrocities around the world that have occurred since the Holocaust. Rieff is surely correct that the prevalence of Holocaust memory and education in Germany and elsewhere did not prevent the Cambodian genocide of the Khmer Rouge or the Rwandan genocide of 1994 or the ethnic violence that riddled the Balkans in the 1990s. In reality, it is easy to cite such horrific examples to prove that memory is not preventive, but that is only because it is much

\footnotetext{
${ }^{1}$ David Rieff, In Praise of Forgetting: Historical Memory and Its Ironies (New Haven: Yale University Press, 2016), 39.

${ }^{2}$ Aleida Assman, Cultural Memory and Western Civilization: Functions, Media, Archives (Cambridge, UK: Cambridge University Press, 2011); Paul Connerton, How Societies Remember (New York: Cambridge University Press, 1989); Marianne Hirsch, Family Frames: Photography, Narrative, and Postmemory (Cambridge, MA: Harvard University Press, 1997); Marianne Hirsch, The Generation of Postmemory: Writing and Visual Culture After the Holocaust. (New York: Columbia University Press, 2012); Andreas Huyssen, Present Pasts: Urban Palimpsests and the Politics of Memory (Stanford: Stanford University Press, 2003); Elizabeth Jelin, State Repression and the Labors of Memory, trans. Judy Rein and Marcial Godoy-Anativia (Minneapolis: University of Minnesota Press, 2003); Dominick LaCapra, History and Memory after Auschwitz (Ithaca: Cornell Univ. Press, 1998); Dominick LaCapra, Writing History, Writing Trauma, 2nd ed. (Baltimore: Johns Hopkins University Press, 2014); Alison Landsberg, Prosthetic Memory: The Transformation of American Remembrance in the Age of Mass Culture (New York: Columbia University Press, 2004); Michael Rothberg, Multidirectional Memory Remembering the Holocaust in the Age of Decolonization (Stanford: Stanford University Press, 2009); Diana Taylor, The Archive and the Repertoire: Performing Cultural Memory in the Americas (Durham: Duke University Press, 2003); James Edward Young, The Texture of Memory: Holocaust Memorials and Meaning (New Haven: Yale University Press, 1993); James E. Young, The Art of Memory: Holocaust Memorial in History (New York: Prestel, 1994); James E. Young, At Memory's Edge: After-Images of the Holocaust in Contemporary Art and Architecture (New Haven: Yale University Press, 2002).

${ }^{3}$ Pierre Nora, “Between Memory and History: Les Lieux Des Mémoire," Representations 26, no. Spring (1989), 7-24.

${ }^{4}$ Rieff, In Praise of Forgetting, 83.
}

Kerry E. Whigham, "Remembering to Prevent: The Preventive Capacity of Public Memory" Genocide Studies and Prevention 11, 2 (2017): 53-71. @2017 Genocide Studies and Prevention. 
more difficult to cite the counterexamples, where active remembrance of the past has succeeded at preventing atrocities. It is impossible to prove a non-event, and Rieff takes full advantage of that impossibility. But this fact does not mean that memory has no preventive potential. After all, Germany and the rest of Western Europe have not perpetrated such atrocities since the end of WWII. When I mentioned this fact to Rieff at a conference in Worcester, Massachusetts, ${ }^{5}$ Rieff responded by stating that it is very rare that one country perpetrates two genocides, and therefore it is not proof enough to assert Germany's non-repetition of atrocities as evidence to the potential preventive effects of memory. Rieff clearly does not understand that history of genocide is widely understood as one of the greatest risk factors for future genocides, a point to which I will return shortly. Moreover, he has conveniently forgotten that Germany did, in fact, perpetrate another genocide before the Holocaust, when it wiped out a vast majority of the Herero people and around $50 \%$ of the Nama people of present-day Namibia in the first decade of the twentieth century. Furthermore, it is memory of the violent conflict of WWII and the Holocaust that led to the formation of the European Union, which, for all its flaws, has undoubtedly succeeded at preventing its member states from killing each other-not a small feat given the almost unceasing series of wars and skirmishes that filled the region for centuries prior to the founding of the EU. It is also hard to believe that Germany's response to the current Syrian refugee crisis is not in some way related to a collective memory of the refugees created by Germany during the Third Reich. Of all the EU countries, Germany has accepted by far the largest number of asylum seekers, pursuing refuge from atrocities in their home country. Other factors are, of course, also at play. But is it so far-fetched to think that memory of past violence does not play some contributing role here?

Rieff is indeed correct to say that memory is not always and only preventive. In fact, memory can be used to encourage violence, rather than deter it. The past has provided ample justification for enduring social hostilities or outright violence in places like the former Yugoslavia, IsraelPalestine, and the Great Lakes Region of Africa. As I will explain shortly, memory is, by my definition, the way that the past influences the present and future. Some societies instrumentalize that past to do wonderful things; others use it to rationalize destruction. But to assert, as Rieff does, that the answer in these countries where the past is being used to stoke further violence is to forget is patently absurd. At times, memory is used to prevent. At others, memory is used to incite. But one thing is certain: memory is. And to expect citizens of post-atrocity societies to forget a period of recent violence willfully is as much an example of "magical thinking" as Rieff believes the preventive aspects of memory are. Additionally, it is worth noting that, all too often, those who most adamantly cry for "forgetting" and "moving forward" are not, themselves, victims, but those who most benefit personally from large-scale oblivion. In these cases, "forgetting" becomes a euphemism for outright denial, which, as Gregory Stanton has famously indicated, is itself one of the constituent stages of genocide. ${ }^{6}$

In all post-atrocity societies that utilize various strategies to deal with the past and (hopefully) avert the return of mass violence in the future, these strategies work best when they 1) are motivated by an intention to prevent violence and create social cohesion;2) are supported by adequate financial, social, and political resources; and 3) occur as part of a larger, more comprehensive strategy of dealing with the past. That is to say: memory can certainly fail when it is mal-intentioned or undersupported, just as it can succeed in contributing to prevention when it is directed toward redress, acknowledgement, and unity. In other words, although memory of past violence can certainly be manipulated to justify further violence or social division, it can also be preventive when we work for it to be. But this leads to a much bigger, more important question--and the focus of this article: How exactly can we ensure that memory of the past leads to cohesion, rather than division? Or, rather, how can we remember in order to prevent?

In this article I illustrate the various ways that memory of past genocides and atrocity crimes can contribute to the prevention of future violent conflict. I begin by offering a brief theoretical

\footnotetext{
${ }^{5}$ David Rieff, "Public Lecture" (Emerging Expertise: Holding Accountability Accountable, Clark University, 2017).

${ }^{6}$ I owe this last point of the connection between forgetting and denial to Elazar Barkan, who spoke on these issues during a panel at the Kean University 2017 Summer Institute, Large-Scale Violence and Its Aftermaths, on 25 June 2017; Gregory Stanton, Eight Stages of Genocide (Los Angeles: SAGE, 2008).
} 
overview of memory, what it means in this context, and the role it plays in post-atrocity societies. Next, I draw upon the vast research on risk factors for genocide and mass atrocities in order to provide a framework for thinking about atrocity prevention as mitigating the risk factors associated with conflict history, social fragmentation, and governance. Finally, I offer an array of examples of memory initiatives that mitigate one or more of these risk factors, thus reducing the risk of atrocity. In the end, I argue that, indeed, memory is not always preventive. It can be used to justify horrific violence. But when a concerted and deliberate effort is made to deal with the past with the intention of reducing the hostilities that led to conflict, memory can be a powerful force in the fight to prevent genocide and other atrocities.

\section{Memory vs. History}

To understand the preventive capacity of memory, one must first understand what exactly memory is. Clearly, memory has many different meanings, ranging from the recollection of individual experience to the reality of "sedimented experience," through which the past guides our actions in the world at an often subconscious level. ${ }^{7}$ When scholars and practitioners discuss memory in the context of post-atrocity societies, however, they are most often referring to interpretations of the past that impact the present. It is this form of memory that I address in this article. In his book, Rieff quotes French historian Jacques Le Goff, who writes that "memory only seeks to rescue the past in order to serve the present and future." ${ }^{8}$ Rieff goes on to write that "exercises in collective historical remembrance far more closely resemble myth on one side and political propaganda on the other than they do history." ${ }^{\prime \prime}$ Both Rieff and Le Goff cite this instrumentalization of the past to prove the weaknesses and dangers of memory. In reality, they are right about what memory is, but not so right about what memory does.

Indeed, history and memory are not the same. If we think about History (with a capital $\mathrm{H}$ ) as what actually happened in the past, then memory is the way that past influences the present and the future. Or, rather, to evoke Andreas Huyssen, memory is the way the past is present. ${ }^{10}$ To complicate this a bit, however, what we call history is very often an aspect of memory. Dimitri Nikulin writes, "[M]emory is incapable of adequately representing the past and in fact need not do so, since any act of recollection is an active reconstruction, which is a constructive interpretation or production of the past." ${ }^{11}$ We have all heard the expression, "History is written by the winners." In this case, we are not actually speaking of History (with a capital $\mathrm{H}$, meaning what actually happened), but history (with a lowercase $h$ ): the version of the past that is accepted, at the present moment, at least, as the definitive "truth" of what occurred in the past. This "truth," however, is never the whole truth. It is a selective recounting of the past, told from the perspective of those in power. For every event recounted in a history textbook, there are millions of stories that are not there... and they are usually the stories of the dispossessed, the vanquished, the oppressed, the poor, or, in the basest of terms, the "losers" of history. What we call history, then, is very often a version of memory that has reached a certain level of consensus that places it beyond the boundaries of dispute. In other words, as Henry Kissinger put it, "History is the memory of states."12 But if history can also be a version of memory, then how can we think more deeply about memory?

In State Repression and the Labors of Memory, Argentinean memory scholar Elizabeth Jelin offers three guiding principles when it comes to thinking about memory.$^{13}$ First, she emphasizes that memories are always subjective processes. ${ }^{14}$ The fact that Jelin does not only stress that memory is

\footnotetext{
${ }^{7}$ Christian Gudehus, "On the Significance of the Past for Present and Future Action," in Theorizing Social Memories:

Concepts and Contexts, ed. Gerd Sebald and Jatin Wagle (London: Routledge, 2016), 84-97.

${ }^{8}$ Qtd. in Rieff, In Praise of Forgetting, 22.

${ }^{9}$ Ibid.

${ }^{10}$ Huyssen, Present Pasts.

${ }^{11}$ Dmitri Nikulin, "Introduction: Memory in Recollection of Itself," in Memory: A History, ed. Dmitri Nikulin (New York: Oxford University Press, 2015), 25.

${ }^{12}$ Qtd. in Howard Zinn, A People's History of the United States (New York: HarperCollins, 2005), 9.

${ }^{13}$ Jelin, State Repression and the Labors of Memory.

${ }^{14}$ Ibid., $x v$.
} 
subjective, but that it is a process is essential. It is through the process of memory-making that new subjectivities are formed. This process can absolutely lead to the formation of hostile or violent subjectivities, but, when done in a more productive way, can create a conscientious population that works actively against the recurrence of violence in the future. One aspect of this process is the implementation of memory initiatives, and it is here where the preventive potential of memory arises. I return to memory initiatives later in this article.

Second, Jelin writes that memories are always "the object of disputes, conflicts, and struggles."15 She continues, "This premise involves the need to focus attention on the active and productive role of participants in these struggles. It is they who generate meanings of the past, framed by the power relations in which their actions are embedded in the present."16 I stated before that memory is, but it is perhaps better to say that memory will be. In post-atrocity societies, it is inevitable that the violence of the past will be remembered on a grand scale. How that memory develops will be influenced significantly by the members of that society who advocate for remembrance of the past - the people at the vanguard of public memory production, who Jennifer Jordan refers to as memorial entrepreneurs. ${ }^{17}$ Those memory-makers could be like the Mothers of the Plaza de Mayo, the group of Argentinean women who continue to demand - peacefully, yet forcefully - the return of their disappeared children, bringing forth their message of human rights for all as they do so. But those memory-makers could also be like the leadership of Republika Srpska and Serbia in the Balkans, who continue to evoke the past to justify antagonistic and often genocidal rhetoric against Bosniaks in the present.

The fact that memories are disputed and contested is not actually, on its own, a bad thing. In fact, as I will argue later, a society that allows for an active contestation of the past may even be less prone to atrocities than those with a specific version of the past that is accepted whole cloth by all. The problem comes when people, like Rieff, believe that only one version of the past can and should exist. This assumption is understandable. After all, in post-atrocity societies, we constantly refer to the phenomenon of collective memory, a concept developed by Maurice Halbwachs to describe the fact that all individual memories are formed through the social framework of which the individual is a part. ${ }^{18}$ But the grammatical singular of collective memory is deceptive. As memory scholar James E. Young argues, it is better to think in terms of collected memory: "the many discrete memories that are gathered into common memorial spaces and assigned common meaning."19 Here, Young refers in different words to the same process of "disputes, conflicts, and struggles" that Jelin evokes. Collective or cultural memory is formed through the interaction of millions of individual memories, and often those interactions are not without contention. When this process is intentionally directed toward the goals of social cohesion or atrocity prevention, however, it can forge a relationship with the past that brings people together rather than divides them. ${ }^{20}$

Finally, Jelin writes that, when examining memory, one must recognize that all memory is specific to the place and moment in which it exists. She writes that "meanings attached to the past change over time and are part of larger, complex social and political scenarios." ${ }^{21}$ Here, we arrive at the point that Rieff most bristles against: the instrumentalization of memory for political purposes. Memory certainly always exists within the political sphere, but so, too, does history. When we recognize the contextuality of memory, however, it allows for two things. First, it helps us understand that memory is always related to power and forged through relations of power. This can, at times, be good for some, and bad for others. Either way, the fact that memory is contextually specific means that it is not permanent-which leads to the second point. This non-

\footnotetext{
${ }^{15}$ Ibid.

${ }^{16}$ Ibid.

${ }^{17}$ Jennifer A. Jordan, Structures of Memory: Understanding Urban Change in Berlin and Beyond (Stanford: Stanford University Press, 2006).

${ }^{18}$ Maurice Halbwachs, On Collective Memory, trans. Lewis A. Coser (Chicago: University of Chicago Press, 1992).

${ }^{19}$ Young, The Texture of Memory, xi.

${ }^{20}$ Maddison, Sarah. 2016. Conflict Transformation and Reconciliation: Multi-level Challenges in Deeply Divided Societies. New York: Routledge.

${ }^{21}$ Jelin, State Repression and the Labors of Memory, xv.
} 
permanence of memory allows for the possibility of changing the memory narratives that are being instrumentalized to perpetrate further violence or create social division. It also serves as a challenge, however, because it means that the process of building a preventive memory culture is a perpetual one. Social actors must continue to work at this process, as the risk always exists for the past to be instrumentalized to sow the seeds of strife, rather than of community.

This potential of memory to change is exemplified in Edward S. Casey's concept of public memory. Casey develops this term to describe how different memories and memory narratives join together in the public sphere in order "to guarantee the intimate tie between past and future."22 According to Casey, public memory is distinct from social memory and collective memory. He thinks of social memory as memories that are shared by people within the same kinship group, geographical area, or those dedicated to "a common project." ${ }^{23}$ Likewise, he thinks of collective memory as the phenomenon whereby people who have no association can recall the same event, despite never having known each other ${ }^{24}$ For Casey, collective memory describes the reality that different groups can relate to the same past event without having to relate to each other; the event supersedes the people remembering it. Public memory, on the other hand, is when various groups of people come together in the public sphere through the memory of a certain event. Casey writes that collective memory "allows for co-remembering without co-reminiscing and for the massive convergence of those who remember the same thing without knowing each other personally." ${ }^{25}$ Collective memory becomes public memory when those diverse groups of people come together in space, time, and body to remember that past together. Whereas collective memory does not require that the rememberers be together, public memory demands it.

If we accept Casey's proposition, then, we could say that all of the instances where Rieff cites the failure of memory could easily be viewed instead as instances where collective memory failed to bring people together, to transform into public memory. To take the most obvious example, everyone in Bosnia and Herzegovina who lived through it remembers the horrific violence of the 1990s. To date, that memory of past violence has only led to greater social hostility among the country's various ethnic groups. Using Casey's understanding of memory, however, we could argue that the reason it has failed to bring healing or to prevent social fragmentation is because not only has it not transformed into public memory by bringing all sectors of Bosnian society together to remember the past, but it has also failed at even converting into collective memory. What exists in Bosnia today is what Casey would call social memory. Each ethnic group has its own version of the past. Each sees itself as the victim of the others. And there is little place in the public sphere where these different groups interact or come together to form a common, public memory.

Public memory requires bodies to come together in public space, which is why we must think of memory not only as something cognitive or psychological, but also as something embodied and performed. ${ }^{26}$ It is without doubt the case that memory of the past has been and is being used in certain places to justify radical intolerance and unspeakable violence. But for every instance where that is the case, we can find a dozen alternative cases where memory creates cohesion, positive change, and a less violent society. It is often easier, as Rieff does, to point to the cases where memory does the former. I now want to turn to instances where memory does the latter.

\section{Memory and Prevention}

To begin a discussion on the preventive capacity of memory, it is essential to acknowledge the white elephant in the room: proving the preventive capacity of anything is incredibly difficult, especially for those who are skeptical of prevention discourse from the start. To offer incontrovertible evidence that an atrocity has been prevented, one would need to prove that an atrocity was undoubtedly set

\footnotetext{
${ }^{22}$ Edward Casey, "Public Memory in Place and Time," in Framing Public Memory, ed. Kendall R. Phillips (Tuscaloosa: University of Alabama Press, 2004), 17.

${ }^{23}$ Ibid., 21.

${ }^{24}$ Ibid., 23.

${ }^{25}$ Ibid., 25.

${ }^{26}$ Connerton, How Societies Remember.
} 
to take place and, owing to some action, was prevented from taking place. In most cases, however, it is impossible to prove a non-event. Nevertheless, what we can do is look to the extensive research we have relating to the risk factors for atrocity and see what memory initiatives have successfully mitigated one or more of these factors.

The last decade has seen a proliferation of early-warning systems that draw from qualitative and quantitative data to predict the risk for genocide, state-led mass killing, and/or atrocities. Some of the most well-known and respected of these systems include the Atrocity Forecasting Project out of the University of Sydney ${ }^{27}$, the United Nation's Framework of Analysis for Atrocity Crimes, ${ }^{28}$ the Minorities at Risk Project out of the University of Maryland, ${ }^{29}$ the United States Holocaust Memorial Museum's Early Warning Project, ${ }^{30}$ and Barbara Harff's model of risk factors for genocide and politicide. ${ }^{31}$ Each of these systems utilizes a varying array of risk factors and data to measure risk for atrocity. In Confronting Evil: Engaging Our Responsibility to Prevent Genocide, ${ }^{32}$ social psychologist and genocide prevention scholar James Waller performs a thorough analysis of the wide swath of risk factors identified in these systems to compile a comprehensive list of factors that draws from the strengths of each. The result is a list of twenty risk factors that cut across many of these earlywarning systems and that fall into four different categories, which I discuss below. I posit that memory initiatives can be identified as preventive when they succeed at mitigating or eliminating any of the identifiable risk factors that lead to atrocity. As such, I plan to demonstrate how memory initiatives in a selection of post-atrocity societies have succeeded at mitigating these risk factors, and therefore have made the recurrence of violence less likely.

Waller's risk-assessment model indicates twenty risk factors for atrocity that spread across four different categories: governance, conflict history, economic conditions, and social fragmentation. Each of these categories contains five specific risk factors that fall within its purview. For the purposes of this article, I will focus on the role that memory initiatives have played and can play in mitigating the risk factors associated with three of these categories: conflict history, governance, and social fragmentation. I take my definition of memory initiative from Impunity Watch's Policy Brief on "Guiding Principles of Memorialization," which defines a memory initiative as

any activity that aims to commemorate or enhance understanding of a conflictive past, including - but not limited to-the erection and maintenance of memorials and monuments, the operation of museums and exhibits, traditional ceremonies and rituals, musical and theatrical performances on relevant topics, the running of educational, awareness-raising, dialogue and remembrance programs, the teaching of history, and the gathering and preservation of information. ${ }^{33}$

This definition offered by the policy brief demonstrates the vast gamut of memory initiatives that exist. In the remainder of this article, I focus on an array of memory initiatives to evaluate their capacity to mitigate risk factors for atrocity. By offering specific examples of memory spaces and practices in diverse post-atrocity societies, I demonstrate how memory initiatives can and have mitigated the risk factors associated with conflict history, social fragmentation, and governance.

\footnotetext{
${ }^{27}$ University of Sydney, "Atrocity Forecasting Project," accessed August 21, 2017, http://sydney.edu.au/arts/research/ atrocity forecasting/.

${ }^{28}$ United Nations, "Framework of Analysis for Atrocity Crimes: A Tool for Prevention" (UN Office of the Special Advisers on Genocide Prevention and the Responsibility to Protect, 2014).

${ }^{29}$ University of Maryland, "Minorities at Risk Project," accessed June 21, 2017, http://www.mar.umd.edu/.

${ }^{30}$ United States Holocaust Memorial Museum, "Early Warning Project - United States Holocaust Memorial Museum," accessed June 21, 2017, https://www.ushmm.org/confront-genocide/how-to-prevent-genocide/early-warning-project.

${ }^{31}$ Barbara Harff, "Assessing Risk of Genocide and Politicide," in Peace and Conflict: A Global Survey of Armed Conflicts, SelfDetermination Movements, and Democracy, ed. Monty G. Marshall and Ted Robert Gurr (College Park: University of Maryland Press, 2005), 57-61.

${ }^{32}$ James Waller, Confronting Evil: Engaging Our Responsibility to Prevent Genocide (New York: Oxford University Press, 2016).

${ }^{33}$ Impunity Watch, “Policy Brief: Guiding Principles of Memorialization,” (Impunity Watch, January 2013), 3.
} 


\section{Conflict History}

Perhaps the primary risk factor that memory initiatives as a whole mitigate are those associated with conflict history. Across numerous risk assessment models, including Waller's, one of the clearest risk factors for atrocity is the existence of a past atrocity. ${ }^{34}$ The reasons why conflict history presents such a dangerous risk factor for atrocity is in dispute. Scott Straus highlights several potential reasons: perhaps it is because the former implementation of systematic discrimination and mass killing conditions leaders to see it as a viable option, or perhaps it has more to do with a combination of past violence and impunity in its aftermath, signaling to perpetrators that such actions will not result in punishment. ${ }^{35} \mathrm{I}$ tend to lean toward the argument that past systematic discrimination resulting in mass killing demonstrates the potential by a society at large to write off certain groups as outside the realm of moral responsibility - a point to which I will return. Whatever the reason, the risk factors associated with prior genocides or politicides are clear. Unfortunately, this risk factor is one that cannot ever be completely eliminated; if a society experienced a genocide, nothing can make that genocide go away. In this case, however, there are ways of mitigating the power of this risk factor. Waller writes, "[C]onflict history in a state or region is a nonmodifiable risk factor for the onset of future genocide-if it happened, it cannot be unhappened. What can be modified, however, are the ways in which that history is remembered, taught, processed, and understood." ${ }^{36}$ In other words, conflict history presents varying degrees of risk based on the way it manifests in public memory - the way it functions in contemporary discourse and practice.

For this reason, memory is just one aspect of a much bigger process that every post-atrocity society must face in the aftermath of large-scale, systematic violence. A single word emerged in post-WWII Germany to describe this process: Vergangenheitsbewältigung, which literally means, "coming to terms with the past." Today, however, memory is considered a process that is both a part of and exceeds the framework of transitional justice. Transitional justice (TJ) is the term that has emerged to describe the ways a society deals with the human rights abuses of its past. Even though its name may imply that it involves only judicial means of dealing with the past (e.g. the criminal prosecution of perpetrators), TJ refers both to the juridical and non-juridical means by which a society addresses past atrocities and systematic human rights violations. As TJ has expanded as a field over the past several decades, certain keywords or themes have become associated with its processes. Each of these words extends beyond the political and the pragmatic. Indeed, each has a kind of moral or ethical value attached to it, as well. These words inevitably come up in the aftermath of mass atrocity, and they highlight what many people feel is at stake when it comes to dealing with the past. They are words like truth, justice, and reconciliation. They also include memory.

Yet, the notion of memory and public memory formation also exceeds the framework of TJ-a rubric that focuses most especially on the role the state plays in dealing with the past. ${ }^{37}$ Indeed, when it comes to memory, the state is not the only, or even the most important, actor. The idea of remembering the past in order to honor those who were lost and to guarantee the non-recurrence of violence, however, is central to TJ. TJ is traditionally framed as a backward-looking process, which seeks to address past harms and to initiate reforms based on what occurred in the past. There is a growing literature, however, that depicts TJ equally as a forward-looking process that, through mechanisms like truth commissions, criminal prosecutions, institutional reform, and various acts of reparations, creates a society that is more equipped to prevent future violence through an

\footnotetext{
${ }^{34}$ Harff, "Assessing Risk of Genocide and Politicide"; Waller, Confronting Evil; Scott Straus, Fundamentals of Genocide and Mass Atrocity Prevention (Washington, DC: US Holocaust Memorial Museum, 2016); B.E. Goldsmith et al., "Forecasting the Onset of Genocide and Politicide," Journal of Peace Research 50, no. 4 (2013), 437-52.

${ }^{35}$ Straus, Fundamentals of Genocide and Mass Atrocity Prevention.

${ }^{36}$ Waller, Confronting Evil, 162.

${ }^{37}$ In almost every transitional justice process, civil society has an incredibly influential role to play. Indeed, it is often the driving force for transitional justice measures. In the end, however, the actual policies and mechanisms of TJ are largely implemented by the state, not by civil society.
} 
engagement with the past in what Waller refers to as downstream prevention. ${ }^{38}$ Broadly speaking, then, $\mathrm{TJ}$ is a process to mitigate the risk factors of conflict history.

One category of memory initiative that both fits within and exceeds this framework of TJ is the creation of sites of memory and memorials. This vast category of memory initiatives includes, among other things, former sites of atrocity, memorials, monuments, and memory museums. Memorials and monuments can be an aspect of transitional justice in a number of ways. For one, they can serve as a form of symbolic reparations to victims of violence and oppression. By creating official sites of memory that honor those who suffered or died during periods of extreme violence, the state can acknowledge and legitimize that suffering. In this way, memorials can provide a sense of justice, giving victims a feeling that their suffering is recognized. Memorials can also be a site for truth-telling, where the story of what happened in the past can be transmitted to new generations. Sites of memory can be potential sites of reconciliation, in that they can provide a space for groups to come together around shared or even contested narratives of the past.

Political scientist Louis Bickford argues, however, that memorials do not only serve as a component of transitional justice by offering redress for past violations of human rights. Thoughtfully constructed sites of memory also play a role in preventing future violence by reducing some of the risk factors presented by conflict history. ${ }^{39}$ According to the authors of Memorialization and Democracy: State Policy and Civic Action, a report from the 2007 conference held in Santiago, Chile, which brought together memory scholars and practitioners from around the world to discuss the relationship between spaces of memory and democracy:

Memorials whose goal is to prevent the repetition of past abuses will ask us not only to remember the victims, but to look inward and think critically about our history and what forces within society or ourselves unleashed the demons of war, racism, or political oppression. If deliberately designed as open forums, they also have the potential to be part of broader democratic reconstruction by fostering dialogue that helps citizens come to terms with the past and understand its relation to the present and future. Memorials conceived of as more than sacred space or symbolic reparations can thus form an integral part of the longterm objectives of transitional justice. ${ }^{40}$

When developed within the framework of a conscientious strategy to relate the past to the present and future, memory sites can mitigate the risk factors associated with conflict history by framing the past as not fully past and by creating spaces for active engagement with that history.

One clear risk factor that sites of memory can serve to mitigate is what Waller calls the presence of past cultural trauma. Just as an individual who has experienced a traumatic event can be haunted by that event in a way that impedes his or her ability to function positively in the present, societies that have experienced a traumatic past are often impeded by the ghosts of that past violence. Sites of memory can provide a venue for what Dominick LaCapra calls the "working through" of this past cultural trauma ${ }^{41}$ According to LaCapra, who elaborates upon the concept of Sigmund Freud, trauma must be "worked through" productively in order to prevent it from "acting out," that is, from constantly re-manifesting as a violent, damaging force. ${ }^{42}$ LaCapra writes, "[Working through] means coming to terms with the trauma, including its details, and critically engaging the tendency to act out the past and even to recognize why it may be necessary and even in certain

\footnotetext{
${ }^{38}$ Waller, Confronting Evil; Clara Ramírez-Barat, "Introduction: Transitional Justice and the Public Sphere," in Beyond Outreach: Transitional Justice, Culture, and Society, ed. Clara Ramírez-Barat (New York: SSRC, 2013), 26-45; Alexander Laban Hinton, Transitional Justice: Global Mechanisms and Local Realities after Genocide and Mass Violence (New Brunswick: Rutgers University Press, 2011); Pablo de Greiff, "Justice and Reparations," in Transitional Justice: Handbook for Latin America, ed. Félix Reátegui (New York: International Center for Transitional Justice, 2011), 377-408.

${ }^{39}$ Louis Bickford, "Memoryworks/Memory Works," in Transitional Justice, Culture, and Society: Beyond Outreach, ed. Clara Ramírez-Barat (New York: Social Science Research Council, 2014), 491-528.

${ }^{40}$ Sebastian Brett et al., "Memorialization and Democracy" (Santiago: FLACSO Chile, International Center for Transitional Justice, and International Coalition of Historic Museums of Conscience, June 20, 2007), 6.

${ }^{41}$ La Capra, History and Memory after Auschwitz; La Capra, Writing History, Writing Trauma.

${ }^{42}$ Ibid.
} 
respects desirable or at least compelling." ${ }^{43}$ Although this model, as originally conceived, deals primarily with individual trauma, Waller's risk assessment model demonstrates how this metaphor also applies on the societal level. If a society that has experienced past cultural trauma does not proactively work through that history, it remains a risk factor for the re-emergence of violencethat is, the "acting out" of that cultural trauma through renewed acts of physical destruction.

Sites of memory have a real role to play in the working through of cultural trauma, and therefore in the mitigation of atrocity risk. They can do this in a number of ways. First, sites of memory can ensure that the truth about the past is widely known and understood, a first step in working through past trauma. Memorial museums are one prevalent and effective type of memory site whose primary goal is to inform the public about the facts of what actually occurred. The Museum of Memory and Human Rights in Santiago, Chile, is one example of such a museum. Inaugurated in 2010, this museum serves both as a memorial to the victims of oppression under Augusto Pinochet's military dictatorship (1973-90), and as a museum providing a comprehensive historical overview of the events that occurred during this period of violence, as well as those that preceded and followed it. According to the Museum's website:

The Museum of Memory and Human Rights is a space designed to give visibility to the human rights violations committed by the Chilean State between 1973 and 1990, to dignify the victims and their families, and to stimulate reflection and debate on the importance of respect and tolerance, so that these acts will never again be repeated. ${ }^{44}$

This mission statement demonstrates how the museum serves a dual purpose. By informing visitors about what exactly occurred during the period of violence, it is simultaneously encouraging a working through by, in their words, "[stimulating] reflection and debate on the importance of respect and tolerance." 45 In other words, the museum serves to bridge the gap between the past and present, asking what lessons can be learned from the past to ensure that it does not repeat itself.

Sites of memory can also aid in the working through of past trauma by literally transforming former sites of death into sites of life and community. Some of the most powerful sites of memory are former sites of atrocity that have been converted into memory spaces, for examples, the former concentration camps of Europe and the former detention and torture centers of Latin America. When these sites of death become active and vibrant sites of memory, the spaces that once worked to produce death are transformed into spaces that both educate visitors about the past and hopefully produce within them a personal commitment to preventing the recurrence of such violence. Examples abound of such creative uses of memory space.

The District Six Museum in Cape Town, South Africa, is located within the bounds of the District Six National Heritage Site, which saw the forced displacement of tens of thousands of mostly black South Africans during Apartheid. Today, the District Six Museum educates visitors about the history of Apartheid, using the story of District Six to tell the broader story of this oppressive regime as a whole. It is not only a place of history, however. The directors of the District Six Museum have created an array of programs that ensure the lessons of Apartheid are not solely those of a distant past; rather, the threat of race-based oppression is ever-present and must be actively resisted. Through oral history projects, South African youth are trained in oral history methodologies so that they record the stories of the generations that lived through Apartheid. Projects like this help to ensure the preservation of memory related to this past. The museum also hosts a number of projects that more directly connect the history of Apartheid with current issues of racism and human rights abuses. The Anti-Racism and Human Rights Project, coorganized with the British Council in 2006/2007, offered training to youth on issues of racism and human rights, before helping the young participants to develop and implement community-based projects addressing these issues in their own communities. Likewise, the 2006 Zenit Exchange

\footnotetext{
${ }^{43}$ LaCapra, Writing History, Writing Trauma, 144.

44 "Sobre El Museo: Museo de La Memoria Y Los Derechos Humanos," accessed June 21, 2017, https://ww3. museodelamemoria.cl/sobre-el-museo/; my translation.

${ }^{45}$ Ibid.
} 
Programme with the Malmö Museum of Sweden organized international exchanges for students to "[investigate] global issues of poverty, unfair trade, gender, racism, human rights, health and welfare." 46 Through programs like these, the memory workers of the District Six Museum connect "then" with "now", demonstrating that learning about past violence can also lead to action and social transformation in the present. The projects created by these youth, then, serve to mitigate in some way another risk factor of atrocity: records of serious violations of international human rights and laws. ${ }^{47}$ According to the UN's Framework for Analysis of Atrocity Crimes, "Societies that have a history of violence and serious violations of international human rights and humanitarian law or atrocity crimes, or where these are currently taking place, can be more prone to further atrocity crimes." ${ }^{48}$ The atrocity crimes of Apartheid are an historical fact that cannot be altered. The projects initiated by the participants in these programs, however, use the lessons of Apartheid to address current violations of human rights or the unequal access to goods and services; in the process, they curtail the effects of this risk factor, thus making future atrocity crimes less likely.

These examples from the District Six Museum illustrate how sites of memory on their own can do very little to mitigate the risks for atrocity. Rather, it is how these sites are used that determines their preventive potential. One of the productive ways to ensure that a memorial space remains alive and active-a space that pushes memory of the past into the everyday so that it can be preventive, rather than a space that sequesters the past away, keeping the discomforts of prior violence out of sight and mind - is to make sure these sites of memory themselves become venues for other memory initiatives. ${ }^{49}$ This idea is supported by Judy Barsalou and Victoria Baxter when they call for a move away from "old memorial and museum traditions of creating static spaces." They continue, quoting Liz Ševčenko, "The goal is to make or preserve places for "performances of democracy, not static representation of national identity."'50 Spaces of memory can be more successfully preventive when they are also spaces for civil society activism, for the coming together of dissenting groups in historical dialogue, for the transmission of memory to future generations, and for the utilization of the arts to keep these spaces full of life, rather than only full of past death. The one point I hope to emphasize here is that memorial spaces on their own are completely insufficient. The spaces must be activated and filled with the bodies of rememberers, who must in turn be inspired and activated by the space to go forth and do the difficult, yet necessary work of prevention. In other words, the preventive capacity of memory initiatives is not only related to how they address the risk factors related to conflict history, but also how they bring people together in a way that addresses a second category of risk factors for atrocities: social fragmentation.

\section{Social Fragmentation}

Another capacity of memory initiatives for the prevention of atrocity involves the mitigation of risks associated with what Waller refers to as social fragmentation. During periods of genocide and mass atrocity, two processes that are common across almost all cases are the fragmentation and atomization of civil society. ${ }^{51}$ Fragmentation involves the breaking down of societies into specific identity groups so that these groups eventually cease to interact or associate with each other. During the Holocaust, for instance, Jews and other "undesirable" social groups were isolated from the larger German society. In Rwanda, Hutus and Tutsis - two groups that had lived together in relative harmony for many decades before the 1960s-reached levels of fragmentation

\footnotetext{
46 “District Six Museum I Education," accessed June 21, 2017, http://www.districtsix.co.za/Content/Education/Learners/ BalulekaYouth/Background/index.php.

${ }^{47}$ Waller, Confronting Evil, 170.

${ }^{48}$ United Nations, "Framework of Analysis for Atrocity Crimes," 11.

${ }^{49}$ Kerry Whigham, "Filling the Absence: The Re-Embodiment of Sites of Mass Atrocity and the Practices They Generate," Museum and Society 12, no. 2 (2014), 88-103.

${ }^{50}$ Judy Barsalou and Victoria Baxter, “The Urge to Remember: The Role of Memorials in Social Reconstruction and Transitional Justice" (Washington, DC: United States Institute of Peace, January 2007), 14.

${ }^{51}$ Hannah Arendt, On Violence (New York: Harcourt, Brace, Jovanovich, 1970); Hannah Arendt, The Origins of Totalitarianism (New York: Harcourt, Brace \& World, 1968); Guillermo O'Donnell, Counterpoints: Selected Essays on Authoritarianism and Democratization (Notre Dame: University of Notre Dame Press, 1999); Waller, Confronting Evil.
} 
that allowed for the attempted destruction of one of these groups. In turn, atomization refers to the breaking down of even these separate identity groups into sole individuals who feel so alone and so threatened by perpetrator regimes that they fear even coming together with other victims to organize against the structures working against them. Hannah Arendt points out that this atomization is particularly indicative of totalitarian regimes, like the Soviet Union. ${ }^{52}$ Argentinean political scientist Guillermo O'Donnell articulates how this same type of atomization was present in the military dictatorships of Latin America. ${ }^{53}$ When civil society is not only fragmented, but also atomized, it becomes incredibly difficult to prevent the rise of genocidal or atrocity regimes or resist their exercise of power once they have already taken control.

A fragmented and atomized civil society is a notable risk factor for atrocity. Waller writes, "Where social cohesion can unite a people and strengthen a society, social fragmentation splinters a people, reduces the resiliency of a society, and places it at increased risk for violent or genocidal conflict." ${ }^{54}$ Likewise, a society within which different identity groups interact and are able to organize collectively to express their desires and exercise their rights is less likely to fall victim to genocide or atrocity. According to the UN Framework for Analysis, societies become more resilient and less likely to commit atrocities by "supporting a strong and diverse civil society and a pluralistic media." ${ }^{55}$ Sites of memory can play an integral role in undoing the fragmentation of groups and encouraging social cohesion around shared memories of the past.

If one of the principal goals of perpetrator regimes is to fragment and isolate civil society groups, oftentimes positioning them against each other, sites of memory can be sites where some of these fragmented groups can both literally and figuratively come together again. Sites of memory provide physical spaces within which those affected and torn apart by that violence can unite again, leading to new levels of social cohesion, and thus mitigating some of the risk factors associated with social fragmentation. In other words, sites of memory can be key components in the production of Casey's concept of public memory: memory produced through the coming together of individuals in the public sphere in order to remember or confront the past collectively.

During Argentina's last military dictatorship (1976-83), most public interaction was criminalized. Labor unions and political parties were declared illegal, and even stopping on the street to speak with someone was suspect. There was little to no room in the public sphere for individuals to come together and resist the violent regime. When the dictatorship fell, the public sphere was reopened, and Argentina began a vigorous, though brief, campaign of what today we would call transitional justice, including the creation of the world's first truth commission ${ }^{56}$ and the prosecution of the architects of the dictatorship. Nonetheless, the threat of another military coup soon overwhelmed these efforts, and for around two decades the country experienced a culture of impunity where the crimes of the past went unpunished and largely unacknowledged. This shifted in the early 2000s, however, with the election of Nestor Kirchner as president. Kirchner and his government reopened the books on the past and began again the work of dealing with its legacy.

One of the key moments in this turning back to the past came on the 28th anniversary of the military coup, 24 March 2004, when Kirchner visited the Escuela Superior Mecánica de la Armada (ESMA), the dictatorship's largest former detention and torture center, where some 5000 Argentineans were tortured and killed. Until that day, the site was still under military control. In a gesture still remembered and discussed today, Kirchner had a soldier remove from the wall the paintings of the leaders of the dictatorship, before opening the gates of ESMA to the public, declaring it an official site of memory. ${ }^{57}$ Today, ESMA hosts the official space of memory in the

\footnotetext{
${ }^{52}$ Arendt, The Origins of Totalitarianism.

${ }^{53}$ O'Donnell, Counterpoints: Selected Essays.

${ }^{54}$ Waller, Confronting Evil, 181.

${ }^{55}$ United Nations, "Framework of Analysis for Atrocity Crimes," 3.

${ }^{56}$ Some point to Uganda's 1974 Commission into the Disappearances of People as the first truth commission. Although this may be true, this commission was established by Idi Amin to account for the people that he and his regime killed. Furthermore, this truth commission did not stop further killing from happening, but occurred within the time-frame of the perpetrator regime. As such, it is difficult to think of this as a real example of transitional justice.

${ }^{57}$ Memoria Abierta, Memorias En La Ciudad: Señales Del Terrorismo de Estado En Buenos Aires (Buenos Aires: Eudeba, 2009);
} 
building where these victims were tortured and imprisoned. The complex also includes a cultural center that features art exhibitions, theatrical performances, concerts, conferences, a bookstore, and a café. Furthermore, the majority of the other buildings on the premises were given to civil society organizations working toward the promotion of memory and human rights. In other words, this site of violence and death has now been transformed into a space of life. Argentineans visit the space every day, not only to remember the violent past, but also to work actively toward the prevention of such violence in the future. By including cultural events and a café in the space, ESMA has also become a space of community. During the period of the dictatorship, Argentinean society was completely fragmented and atomized by the violent regime. Today, the site that represented the pinnacle of this violence is a site for bringing together the people who were once its victims, undoing some risk factors associated with social fragmentation in the process. ${ }^{58}$

The example of ESMA demonstrates how sites of memory can literally bring together fragmented groups, thus mitigating some of the risk factors associated with fragmentation. Sites of memory can also mitigate the risk factors of social fragmentation in more figurative ways. One of the principal reasons that social fragmentation is a risk for genocide and atrocity is because it contributes to excluding groups from what genocide scholar Helen Fein calls the moral universe or universe of moral obligation of the potential perpetrator. ${ }^{59}$ When a certain social group exists outside the universe of moral obligation of other groups, it can experience a form of social death that can precede physical killing. ${ }^{60}$ Waller writes, "Genocide inflicts a social death which makes the victims' lives, and their termination, meaningless." ${ }^{11}$ Part of the process of mitigating the risk factors associated with social fragmentation, then, involves making the lives of fragmented groups meaningful to each other again, ensuring that all social groups exist within each other's universe of moral obligation. This difficult task involves the generation of empathy, and memory initiatives have a role to play in this process, as well.

One key form of memory initiative connected to undoing social fragmentation and generating empathy between groups is historical dialogue programs. Elazar Barkan, perhaps the preeminent scholar in this field of historical dialogue, writes:

Conflict between groups is often transgenerational, and the historical animosity remains if it is not addressed. Fear and desire for revenge often linger and inform the policies of the groups involved, and are prone to be awakened by nationalists and fundamentalists as carriers of xenophobia. Historical dialogue aims to diffuse such hatred by engaging government and civil society in conversations about history and introducing empathy and even sympathy toward the other. Historical dialogue takes place directly and explicitly when two sides are engaged in joint historical writing, such as through a bilateral commission [...], joint civil society projects, or other ways of producing historical knowledge. ${ }^{62}$

Particularly in cases of intractable conflict-for example, Israel Palestine or the Balkans-opposing groups rarely interact with each other, much less attempt to understand the other's point of view. As such, the groups remain fragmented, outside the other's realm of moral obligation. Historical dialogue programs are a specific type of memory initiative that bring together representatives from these opposing groups to begin a dialogue. Importantly, the end goal of this dialogue is not necessarily consensus or total agreement on what occurred in the past and who is responsible. Rather, historical dialogue can be preventive primarily by bringing fragmented groups who never interact into the same space and secondarily by reaching a space of mutual

Marcelo Brodsky, ed., Memory under Construction (Buenos Aires: La Marca Editora, 2005).

${ }^{58}$ Whigham, "Filling the Absence."

${ }^{59}$ Helen Fein, Genocide: A Sociological Perspective (London: Sage, 1990).

${ }^{60}$ Patterson Orlando, Slavery \& Social Death: A Comparative Study (Cambridge, MA: Harvard Univ Press, 1985).

${ }^{61}$ James Waller, Becoming Evil: How Ordinary People Commit Genocide and Mass Killing (New York: Oxford University Press, 2007), 197.

${ }^{62}$ Elazar Barkan, "Historical Dialogue and the Prevention of Atrocity Crimes," in Reconstructing Atrocity Prevention, ed. Sheri P. Rosenberg, Tibi Galis, and Alex Zucker (New York: Cambridge University Press, 2015), 182. 
respect and understanding in which opposing positions can exist in parallel without resulting in violent conflict.

Ensuring free and open debate about the past is not always easy, especially when certain groups uphold a version of the past that rationalizes the violence that occurred. But if those voices are silenced completely or left out of the public sphere, societies risk polarizing these groups, encouraging factionalisms that can become quite dangerous and lead to the perpetration of further atrocities. ${ }^{63}$ Genocide scholar Scott Straus frames this notion a different way. He argues that genocides and other forms of mass categorical violence require a strong founding narrative, or a "preexisting ideological framework," which justifies or legitimates violence toward a specific group identity. ${ }^{64}$ Straus stresses, however, that these violent founding narratives can and have been mitigated in a number of cases by strong counternarratives, which refute the ideological bases for violence that the founding narratives provide. Obviously, the development of counternarratives alongside other narratives requires an open and active public sphere, where different narratives can exist and discursively shape each other. Surely there is some risk involved in this openness, because it can allow public space for the airing of violent ideologies. This is also not to say that placing a modicum of restriction on the freedoms of speech and expression is wrong. I argue, however, that allowing public space for the expression of all viewpoints, including potentially dangerous ones, can be essential in creating a sense of urgency around the sorts of narratives or counternarratives that stress pluralism, inclusion, and non-violent conflict resolution. Historical dialogue is ultimately about critically examining the founding narratives that may lead to atrocity, while at the same time constructing or reinforcing counternarratives that may potentially prevent it.

Programs for historical dialogue can take a number of forms, but I will highlight two examples here to provide some level of illustration. Today in Bosnia-Herzegovina, there is still no consensus among the major ethnic groups regarding the violence that ripped the country apart in the 1990s. Bosnian Muslims (Bosniaks), Bosnian Serbs, and Croats all have their own versions of the past, and each sees itself as the victim of the other groups. On top of this, the country is incredibly segregated, so most people do not live, work, learn, or interact with anyone aside from those in their own ethnic group. Each group has its own system of education, and while children all have similar math and science curricula, they each learn a completely different version of history.

In the face of this reality, the Center for Peacebuilding in Sanski Most, Bosnia-Herzegovina, is working, in their words, "to rebuild trust and foster reconciliation among the people of BosniaCroats, Serbs, Bosniaks, and others." ${ }^{65}$ The Center has developed a number of programs that bring together members from the different ethnic and religious groups of the country to talk openly and honestly about their own perceptions of the past and of the others. Among the various programs of the Center are their Peace Camps - weeklong gatherings of youth from all of Bosnia-Herzegovina's ethnic groups. For many of the youth who participate in the Peace Camps, it is their first time interacting in a meaningful way with members of the other ethnic groups. They are encouraged to speak about topics that may be otherwise taboo, in an effort to build trust and understanding about the others' perceptions and feelings about the past and the present. Participants are also trained in nonviolent conflict resolution strategies, and those who continue the training go on to lead similar dialogues with primary school children when they return home, giving the Peace Camps a multiplier effect. To date, hundreds of Bosnian youth from all ethnic groups have participated in the Peace Camps, and many of them maintain relationships both with the Center and their fellow participants after the Peace Camps are complete.

Another form of historical dialogue occurs through theimplementation of historical commissions (HCs), which usually involve historians themselves coming together to debate opposing views of

\footnotetext{
${ }^{63}$ Waller, Confronting Evil.

${ }^{64}$ Scott Straus, Making and Unmaking Nations: War, Leadership, and Genocide in Modern Africa (Ithaca: Cornell University Press, 2015), 11.

65 "Mission Statement", Center for Peacebuilding, accessed 9 August 2017, http://unvocim.net/eng/about-us/our-missionand-values/.
} 
the past and reach some level of agreement on how either the past or these disagreements should be presented. This process of historical debate and the construction of some form of "sanctioned" memory can serve to mitigate conflict between groups. Alexander Karn writes, "One interesting feature of the HCs is their ability to produce and circulate mediating narratives in societies where historical injustices have not been fully acknowledged. 'Mediating' refers to the recontextualization of past events to ensure they are presented in a nuanced, explanatory framework, rather than in a caustic, accusatory one."66 In other words, HCs are not necessarily about reaching consensus over the past, but rather finding a way of contextualizing different views of the past so that their potential to ignite violent conflict is reduced.

One such example comes from the Peace Research Institute in the Middle East (PRIME), which in the early 2000s worked with a group of Palestinian and Israeli history teachers to develop a joint history textbook for school children. The result of the process was a textbook that included the Israeli and Palestinian narratives relating to conflict in parallel, translated into both Hebrew and Arabic. According to the organizers of the project, "This would mean that each student would learn not only his/her own narrative, but also the narrative of the other, as a first step toward acknowledging and respecting the other." ${ }^{67}$ In the early stages of development the authors also left a blank space in between the two narratives so that both students and their teachers could include their own perspectives. The long-term effects of this project are yet unclear as the final version of the textbook was only published in $2012,{ }^{68}$ but some of the teachers involved in the project's creation did provide some anecdotal evidence of the early test copies of the text. For example, one Palestinian teacher used the texts in his classroom and asked the students to write their responses: "Some of them expressed an interest in meeting Israeli pupils in order to discuss these texts together. Others wanted to know more about this date or that person, mentioned briefly in the texts. There were reports of students who immediately started to deconstruct the other's narrative. In general, the two narratives evoked a surprise that created interest and curiosity." ${ }^{69}$ Clearly, this shared textbook project has not brought an end to conflict in Israel/Palestine. In fact, both the example from Bosnia and this example demonstrate how difficult it is to mitigate the risk factors of atrocity when governmental actors cease to curtail rhetoric that only exacerbates division. But they also exemplify the hope of generating a transformation in the grassroots that could eventually have some impact on state discourse, as well. This is not to say, however, that memory initiatives cannot have an impact in mitigating risk factors for atrocity associated with the third and final category we will examine: governance.

\section{Governance}

Under the category of governance, Waller outlines five risk factors for atrocity: The first relates to regime type. Current research shows that atrocities are far more likely to occur under autocratic governments than democratic governments. Second, states that suffer from a legitimacy deficitthat is, states that are not perceived as legitimate by their own citizens-are more at risk for atrocity than those in which the government has the support of its people. Third, states with strong structures for providing basic services, upholding the law, and responding to the needs of the population are less at risk for atrocity than those societies with weak state structures. Fourth, states that exemplify or encourage identity-based polar factionalism, where only certain identity groups are represented in the halls of government, are more at risk for atrocity. Finally, states that implement systematic acts of discrimination against certain groups are at higher risk for atrocity. Examples of such discrimination include "removal of civil liberties, restricting educational access, arbitrary detention or imprisonment, torture as state policy, large-scale illegal round-ups of civilians, the

\footnotetext{
${ }^{66}$ Alexander Karn, "Historical Commissions and Education Outreach: Challenges and Lessons for Transitional Justice," in Transitional Justice and Education: Learning Peace, ed. Clara Ramírez-Barat and Roger Duthie (New York: SSRC, 2017), 308.

${ }^{67}$ Sami Adwan and Dan Bar-On, "Shared History Project: A PRIME Example of Peace-Building Under Fire," International Journal of Politics, Culture and Society 17, no. 3 (2004), 516.

${ }^{68}$ Sāmī 'Abd al-Razzāq' Adwān et al., Side by Side: Parallel Histories of Israel/Palestine (New York: The New Press, 2012).

${ }^{69}$ Adwan and Bar-On, "Shared History Project," 519.
} 
revocation of the right to citizenship, expropriation or destruction of property (including cultural, religious and sacred sites)." ${ }^{\prime 70}$

Ultimately, it may seem unlikely that memory initiatives can have a real impact on risk factors associated with governance, particularly those related to regime type, given that autocratic regimes are unlikely even to allow public memory initiatives that counter the discourse of the regime. Indeed, it is rare that a memory initiative can transform an autocratic government to a democratic one. That said, memory initiatives have often had an impact on bringing state-led impunity to an end, and therefore strengthening the rule of law, a necessary reality in democratic societies. One example of this comes from Argentina, which experienced nearly two decades of impunity for perpetrators of human rights violations during the military dictatorship of 1976-83. In the midst of this period in the mid-1990s, an activist group known as H.I.J.O.S. (the Spanish acronym for Sons and Daughters for Identity and Justice, against Forgetting and Silence) was formed by the sons and daughters of those who had been disappeared by the military juntas during the dictatorship. Through a creative form of street activism known as the escrache, H.I.J.O.S. pointed out the perpetrators living free and unpunished across the country and called on that perpetrator's neighbors to "sentence" them by ostracizing them socially. H.I.J.O.S. constantly evoked the crimes of the past, as well as the activism of their disappeared parents, to transform the state of impunity to one of memory and justice. Their slogan, "If there is no justice, there will be escrache" ("Si no hay justicia, hay escrache") promised that they would continue their activism until the government dismantled the system of impunity and reinstated the rule of law, whereby all perpetrators would be tried for their crimes. H.I.J.O.S. continued making escraches until 2005, when the government reinstated trials against the perpetrators. The role played by civil society and human rights organizations like H.I.J.O.S. was central to the transformation of Argentinean society from a culture of impunity to one of justice. According to Andrea Gualde, former National Director of Legal Affairs of the Secretariat of Human Rights of the Ministry of Justice in Argentina, "It would be impossible to approach a study of our country's recent history without stating the central role played by the human rights movement in the political and social configuration of contemporary Argentina." ${ }^{\prime 1}$

Memory initiatives also have a real role to play in addressing deficits in the legitimacy of the state. One strong example of this comes from Indonesia. For decades, the Indonesian government refused to acknowledge the genocidal violence perpetrated by state and paramilitary actors in the 1960s against so-called "communist subversives." Annie E. Pohlman writes:

Within broader understandings of restorative justice after the end of authoritarianism, Indonesia stands out as an example of how new regimes sacrifice any attempt at restoration or justice for the short-term goals of securing elite support for democratization. This support, however, has come at a high price: a low-quality democracy, the capture of the newly built democratic institutions by oligarchic elites, and now swift back stepping on hard-won reforms to ensure human rights. ${ }^{72}$

In other words, the way that the Indonesian state had (not) dealt with the past resulted in the exacerbation of a number of risk factors: 1) a state legitimacy deficit, 2) a series of weak state structures, and 3) the risk factors associated with state-led discrimination, given that the government was controlled by oligarchs that prevented non-elites from assuming any form of power. In light of these realities, a coalition of forty-seven grassroots organizations declared 2013 the Year of Truth in Indonesia. Participating NGOs spent the year gathering a bevy of video testimonies, which were professionally edited and distributed using YouTube and an array of social media strategies. The Year of Truth culminated in November 2013 with a national forum called "Hearing Testimony," in

\footnotetext{
${ }^{70}$ Waller, Confronting Evil, 159.

${ }^{71}$ Andrea Gualde, "Reparations for Crimes against Humanity as Public Policy: Argentina's Relationship with the Past, From the Individual to the Collective as a Tool for Prevention," trans. Kerry Whigham, AIPR's Policy Papers in Prevention Series (New York: Auschwitz Institute for Peace and Reconciliation, 2015), 27.

${ }^{72}$ Annie E. Pohlman, "A Year of Truth and the Possibilities for Reconciliation in Indonesia," Genocide Studies and Prevention 10, no. 1 (2016), 61.
} 
which survivors testified to the many manifestations of violence during and in the aftermath of the massacres of the 1960s. ${ }^{73}$ The following year, Joko Widodo became the first democratically elected president who was not a member of the traditional ruling elites. Among his campaign promises was to deal more actively with Indonesia's history of abuses, and he began to fulfill this promise in 2016, first by initiating a National Symposium on the massacres of the 1960s, and then by calling for an investigation of the mass graves relating to this period. ${ }^{74}$ Although these two measures represent only the beginning of a process that will hopefully continue, they certainly demonstrate how the civil society memory initiatives of the Year of Truth both marked and contributed to a sea change in the way the Indonesian state would deal with its past. The election of Widodo marked an opening of the political space to non-elites, thus mitigating some of the risk factors related to stateled discrimination, and Widodo's subsequent acknowledgements of the violence of the 1960s-a break from half a century of total silence on the part of the state-has begun the work of repairing the state legitimacy deficit that also presents a risk for future atrocities.

Although it may be true that the most visible and widely discussed aspects of dealing with the past - from truth commissions to criminal prosecution to reparations to institutional reform require the participation of governmental actors, the fact remains that most of these processes initiate through a movement from the grassroots that begins long before the state opts to assume responsibility for these projects. ${ }^{75}$ Through memory initiatives like those outlined above, nongovernmental actors can have a real role in transforming the way the state functions and responds to the past. In the meantime, they are reducing a number of risk factors for atrocity associated with governance by invigorating a public sphere within which their voices are heard and their calls for truth, memory, and justice are answered.

\section{Conclusion}

Rieff is not wrong that memory of the past can be difficult and its instrumentalization can, in some cases, provoke conflict. All of the examples he offers to prove his point, however, are cases where memory is being used to isolate, rather than to bring people together. The atomizing effects of genocidal violence are still in play. There is another potential for memory in these places, however, and that potential does not exist in advocating for memory's elimination (as if that were even possible). Rather, the discomforts and the pain of the past, which are often felt to varying degrees on all sides of the social equation, could provide a starting point for a new conversation - one that leads to new levels of understanding and empathy. It is not an easy process, nor is it a quick one. But here the pliability of memory is actually its greatest asset. The fact that memory narratives can change means that damaging views of the past, which serve to fragment societies, rather than bring them together, can be rewritten. With a great deal of effort, new narratives can be generated... narratives that counter the dangerous incitements of the old narratives and that, as they gain traction, provide a much greater potential of preventing the return of old hostilities in the future. These new narratives, however, will not emerge spontaneously. They require the dedication and intention of memory workers - both at the state and grassroots levels - who endeavor to implement memory initiatives meant not to divide, but to unite.

In this article I have focused on an array of memory initiatives, offering only a handful of examples of the myriad ways these practices have manifested and how they have mitigated, at least partially, some of the risk factors for atrocity associated with conflict history, social fragmentation, and governance. Although these practices are all quite different, and while the kinds of memory initiatives that emerge from within a post-atrocity society are certainly always specific to the cultural and historical contexts of the society itself, all of the practices I highlight have one important thing in common-and it is, for me, the essential quality that makes them

\footnotetext{
${ }^{73}$ Pohlman, "A Year of Truth."

${ }^{74}$ Benny Widyono, "The Legacy of Cold War Era Massacres in Cambodia and Indonesia," in Societies Emerging from Conflict: The Aftermath of Atrocity, ed. Dennis Klein (New York: Cambridge Scholars Publishing, Forthcoming).

${ }^{75}$ Kerry Whigham, "Performing Prevention: Civil Society, Performance Studies, and the Role of Public Activism in Genocide Prevention," in Reconstructing Atrocity Prevention, ed. Sheri P. Rosenberg, Tibi Galis, and Alex Zucker (New York: Cambridge University Press, 2015), 321-51.
} 
potentially preventive. All of these practices center on the coming together of physical bodies in public space in one way or other. It is easy to think about memory as something that happens only in the mind of the individual. In reality, memory is a force that is embodied and that affects the ways our bodies interact with others. When memory isolates or atomizes bodies, it has little chance at being preventive. On the other hand, when it draws people together in the public sphere-even when it leads to nonviolent disputes and contentious debates-memory has a much greater chance of preventing genocidal violence. Of course, memory alone is not enough. Prevention requires an effort from all levels of society: state to civil society, local to global, young to old. To be sure, however, memory can be a factor in prevention. As I said earlier, whether we want it or not, memory will be. How we approach memory is the key to determining whether it will be destructive or will be preventive.

\section{Bibliography}

Adwān, Sāmī, and Dan Bar-On. "Shared History Project: A PRIME Example of Peace-Building Under Fire." International Journal of Politics, Culture and Society 17, no. 3 (2004): 513-21. https://doi.org/10.1023/B:IJPS.0000019616.78447.5e

Adwān, Sāmī 'Abd al-Razzāq', Dan Bar-On, Eyal J Naveh, and Peace Research Institute in the Middle East. Side by Side: Parallel Histories of Israel/Palestine. New York: The New Press, 2012.

Arendt, Hannah. On Violence. New York: Harcourt, Brace, Jovanovich, 1970.

- - - . The Origins of Totalitarianism. New York: Harcourt, Brace \& World, 1968.

Assman, Aleida. Cultural Memory and Western Civilization: Functions, Media, Archives. Cambridge, UK: Cambridge University Press, 2011. https://doi.org/10.1017/CBO9780511996306

Barkan, Elazar. "Historical Dialogue and the Prevention of Atrocity Crimes." In Reconstructing Atrocity Prevention, edited by Sheri P. Rosenberg, Tibi Galis, and Alex Zucker. New York: Cambridge University Press, 2015. https://doi.org/10.1017/CBO9781316154632.010

Barsalou, Judy, and Victoria Baxter. "The Urge to Remember: The Role of Memorials in Social Reconstruction and Transitional Justice." Washington, DC: United States Institute of Peace, January 2007.

Bickford, Louis. "Memoryworks/Memory Works." In Transitional Justice, Culture, and Society: Beyond Outreach, edited by Clara Ramírez-Barat, 491-528. New York: Social Science Research Council, 2014.

Brett, Sebastian, Louis Bickford, Liz Ševčenko, and Marcela Rios. "Memorialization and Democracy." Santiago: FLACSO Chile, International Center for Transitional Justice, and International Coalition of Historic Museums of Conscience, June 20, 2007.

Brodsky, Marcelo, ed. Memory under Construction. Buenos Aires: La Marca Editora, 2005.

Casey, Edward. "Public Memory in Place and Time." In Framing Public Memory, edited by Kendall R. Phillips, 17-44. Tuscaloosa: University of Alabama Press, 2004.

Connerton, Paul. How Societies Remember. New York: Cambridge University Press, 1989.

“District Six Museum I Education." Accessed June 21, 2017. http://www.districtsix.co.za/Content/ Education/Learners/BalulekaYouth/Background/index.php.

Fein, Helen. Genocide: a sociological perspective. London: Sage, 1990.

Goldsmith, B.E., C.R. Butcher, D. Semenovich, and A. Sowmya. "Forecasting the Onset of Genocide and Politicide." Journal of Peace Research 50, no. 4 (2013): 437-52. https://doi. org/10.1177/0022343313484167

Greiff, Pablo de. "Justice and Reparations." In Transitional Justice: Handbook for Latin America, edited by Félix Reátegui, 377-408. New York: International Center for Transitional Justice, 2011.

Gualde, Andrea. "Reparations for Crimes against Humanity as Public Policy: Argentina's Relationship with the Past, From the Individual to the Collective as a Tool for Prevention." Translated by Kerry Whigham. AIPR's Policy Papers in Prevention Series. New York: Auschwitz Institute for Peace and Reconciliation, 2015.

Gudehus, Christian. "On the Significance of the Past for Present and Future Action." In Theorizing Social Memories: Concepts and Contexts, edited by Gerd Sebald and Jatin Wagle, 84-97. London: Routledge, 2016. 
Halbwachs, Maurice. On Collective Memory. Translated by Lewis A. Coser. Chicago: University of Chicago Press, 1992.

Harff, Barbara. "Assessing Risk of Genocide and Politicide." In Peace and Conflict: A Global Survey of Armed Conflicts, Self-Determination Movements, and Democracy, edited by Monty G. Marshall and Ted Robert Gurr, 57-61. College Park: University of Maryland Press, 2005.

Hinton, Alexander Laban. Transitional Justice: Global Mechanisms and Local Realities after Genocide and Mass Violence. New Brunswick: Rutgers University Press, 2011.

Hirsch, Marianne. Family Frames: Photography, Narrative, and Postmemory. Cambridge, MA: Harvard University Press, 1997.

- - - The Generation of Postmemory: Writing and Visual Culture After the Holocaust. New York: Columbia University Press, 2012.

Huyssen, Andreas. Present Pasts: Urban Palimpsests and the Politics of Memory. Stanford: Stanford University Press, 2003.

Impunity Watch. "Policy Brief: Guiding Principles of Memorializaiton." Impunity Watch, January 2013.

Jelin, Elizabeth. State Repression and the Labors of Memory. Translated by Judy Rein and Marcial Godoy-Anativia. Minneapolis: University of Minnesota Press, 2003.

Jordan, Jennifer A. Structures of Memory: Understanding Urban Change in Berlin and Beyond. Stanford: Stanford University Press, 2006.

Karn, Alexander. "Historical Commissions and Education Outreach: Challenges and Lessons for Transitional Justice." In Transitional Justice and Education: Learning Peace, edited by Clara Ramírez-Barat and Roger Duthie, 306-31. New York: SSRC, 2017.

LaCapra, Dominick. History and Memory after Auschwitz. Ithaca: Cornell Univ. Press, 1998.

- - - Writing History, Writing Trauma. $2^{\text {nd }}$ Edition. Baltimore: Johns Hopkins University Press, 2014.

Landsberg, Alison. Prosthetic Memory: The Transformation of American Remembrance in the Age of Mass Culture. New York: Columbia University Press, 2004.

Memoria Abierta. Memorias En La Ciudad: Señales Del Terrorismo de Estado En Buenos Aires. Buenos Aires: Eudeba, 2009.

"Mission Statement." Center for Peacebuilding. Accessed 9 August 2017. http://unvocim.net/eng/ about-us/our-mission-and-values/.

Nikulin, Dmitri. "Introduction: Memory in Recollection of Itself." In Memory: A History, edited by Dmitri Nikulin, 3-34. New York: Oxford University Press, 2015. https://doi.org/10.1093/ acprof:0so/9780199793839.003.0001

Nora, Pierre. "Between Memory and History: Les Lieux Des Mémoire." Representations 26, no. Spring (1989): 7-24. https://doi.org/10.2307/2928520

O'Donnell, Guillermo. Counterpoints: Selected Essays on Authoritarianism and Democratization. Notre Dame: University of Notre Dame Press, 1999.

Patterson Orlando. Slavery \& Social Death: A Comparative Study. Cambridge, MA: Harvard Univ Press, 1985.

Pohlman, Annie E. "A Year of Truth and the Possibilities for Reconciliation in Indonesia." Genocide Studies and Prevention 10, no. 1 (2016): 60-78. https://doi.org/10.5038/1911-9933.10.1.1323

Ramírez-Barat, Clara. "Introduction: Transitional Justice and the Public Sphere." In Beyond Outreach: Transitional Justice, Culture, and Society, edited by Clara Ramírez-Barat, 26-45. New York: SSRC, 2013.

Rieff, David. In Praise of Forgetting: Historical Memory and Its Ironies. New Haven: Yale University Press, 2016.

- - - "Public Lecture." Emerging Expertise: Holding Accountability Accountable. Clark University, 2017.

Rothberg, Michael. Multidirectional Memory Remembering the Holocaust in the Age of Decolonization. Stanford: Stanford University Press, 2009.

"Sobre El Museo : Museo de La Memoria Y Los Derechos Humanos." Accessed June 21, 2017. https://ww3.museodelamemoria.cl/sobre-el-museo/.

Stanton, Gregory. Eight Stages of Genocide. Los Angeles: SAGE, 2008. 
Straus, Scott. Fundamentals of Genocide and Mass Atrocity Prevention. Washington, DC: US Holocaust Memorial Museum, 2016.

- - - Making and Unmaking Nations: War, Leadership, and Genocide in Modern Africa. Ithaca: Cornell University Press, 2015.

Taylor, Diana. The Archive and the Repertoire: Performing Cultural Memory in the Americas. Durham: Duke University Press, 2003. https://doi.org/10.1215/9780822385318

United Nations. "Framework of Analysis for Atrocity Crimes: A Tool for Prevention." UN Office of the Special Advisers on Genocide Prevention and the Responsibility to Protect, 2014.

United States Holocaust Memorial Museum. "Early Warning Project - United States Holocaust Memorial Museum." Accessed June 21, 2017. https://www.ushmm.org/confront-genocide/ how-to-prevent-genocide/early-warning-project.

University of Maryland. "Minorities at Risk Project." Accessed June 21, 2017. http://www.mar. umd.edu/.

Waller, James. Becoming Evil: How Ordinary People Commit Genocide and Mass Killing. New York: Oxford University Press, 2007.

- - - Confronting Evil: Engaging Our Responsibility to Prevent Genocide. New York: Oxford University Press, 2016.

Whigham, Kerry. "Filling the Absence: The Re-Embodiment of Sites of Mass Atrocity and the Practices They Generate." Museum and Society 12, no. 2 (2014): 88-103.

- - - "Performing Prevention: Civil Society, Performance Studies, and the Role of Public Activism in Genocide Prevention." In Reconstructing Atrocity Prevention, edited by Sheri P. Rosenberg, Tibi Galis, and Alex Zucker, 321-51. New York: Cambridge University Press, 2015. https://doi.org/10.1017/CBO9781316154632

Widyono, Benny. "The Legacy of Cold War Era Massacres in Cambodia and Indonesia." In Societies Emerging from Conflict: The Aftermath of Atrocity, edited by Dennis Klein. New York: Cambridge Scholars Publishing, Forthcoming.

Young, James E. At Memory's Edge: After-Images of the Holocaust in Contemporary Art and Architecture. New Haven: Yale University Press, 2002.

- - - . The Art of Memory: Holocaust Memorial in History. New York: Prestel, 1994.

Young, James Edward. The Texture of Memory: Holocaust Memorials and Meaning. New Haven: Yale University Press, 1993.

Zinn, Howard. A People's History of the United States. New York: HarperCollins, 2005. 